\title{
Fostering the Management of Post Office Building from Architectural, Heritage and Urban Design View (Case study: The Solo Post Office, Central Java, Indonesia)
}

\author{
R.Siti Rukayah ${ }^{1 *}$, Shabrina Adine Vania ${ }^{2}$, Sudarmawan Yuwono ${ }^{3}$ \\ ${ }^{1}$ Architecture Department, Engineering Faculty, Universitas Diponegoro, Semarang, Indonesia \\ ${ }^{2}$ Graduated from Architecture Department, Engineering Faculty, Diponegoro University, Semarang, Indonesia \\ ${ }^{3}$ Architecture Department, Universitas Bung Karno, Jakarta, and PT. Pos Indonesia, Bandung, Indonesia \\ *Corresponding author. Email: tututrsiti68@gmail.com
}

\begin{abstract}
There have been many studies on the impact of social media and the presence of freight forwarding services by private parties. Social media and private parties have an effect on post office services in the world and Indonesia. The digital era and the delivery of mail and goods through private sector services has led postal services to do some innovations. There have been several efforts by PT. Pos Indonesia in transforming businesses following the rapid changes in the business environment. The strategy of PT. Pos Indonesia is by conducting transformation covering all aspects of business, human resources, strengthening of subsidiaries, developing new products, and pushing towards digitalization. Other efforts include venturing into financial services and purchasing tickets and payment for electricity, water, and daily necessities. The post office is open longer hours from Monday to Saturday from 08:00 am to 09:00 pm. From several studies, some of the strategies carried out focus on managerial improvement. There is potential for organizational development from an architectural and urban design perspective. The method used in this study was to collect data from the aspects of architecture and urban design. The technique was used to find the potential location and commercial value of buildings - re-documenting architectural building as a research method. There found a possibility for developing the third floor of the post office as a commercial area that supports the potential of the surrounding urban space, which is full of historical values. In Indonesia, the presence of the post offices are usually in the historic cities, and the activity continues today. Due to the presence of social media and competition with private shipping service, the space of post office activities is shrinking. The rest of the unused space can be used for commercial activities in areas that support postal activities, cultural heritage values, and city heritage values. Moreover, the location is close to commercial areas and historical city areas. This recommendation can increase the financial income of PT. Pos Indonesia. This breakthrough finding can answer the question of the collapse of post offices in Indonesia due to the presence of social media and the delivery of goods through private shipping services. These efforts support building conservation activities by the application of adaptive reuse in cultural heritage buildings.
\end{abstract}

Keywords: Solo, Indonesia post office, culture, assets, cultural heritage

\section{INTRODUCTION}

There are many studies on post office services in Indonesia, especially regarding services in the face of competition in the digital era and services between letters and goods through private parties [1,2]. This phenomenon does not only occur in Indonesia but also in various parts of the world. [3-7]. In India, the United States, Ireland, and Malaysia, they competed in innovation in postal services. The post office is a public institution to serve the reception, collection, sorting, transmission, and delivery of letters, postcards, postcards, and other postal services by post at a fee. The post office also serves several customer needs, including selling postal and philatelic items, such as stamps, postcards, envelopes, and equipment for wrapping packages. Inside the post office, there are various counters divided according to the type of service, such as internal mailing counters, overseas mail counters, and postal money orders. In the Indonesian postal service system, the post office is assisted by mail buses and mobile service units such as a post around the city or village. The post office also has a computer rental service that is connected to the internet [8]. 
The Ministry of State-Owned Enterprises (BUMN) has ensured that PT. Pos Indonesia (Persero) is a healthy BUMN. There are several efforts undertaken by PT. Pos Indonesia in transforming its business following the rapid changes in the business environment. The Ministry of BUMN also closely monitors the development of PT. Pos Indonesia so that it will continue to work and carry out its functions [9]. Another fact, companies still provide Universal Post services six days per week, with overseas postal services served 4-5 days per week. [10]. There are six steps to be taken so that the post office will continue to survive. PT. Pos Indonesia also received an A-rating from the leading national rating agency Pefindo. PT. Pos Indonesia is conducting business transformation covering all aspects of business, human resources, strengthening of subsidiaries, developing new products, and others [9]. PT. Pos Indonesia's strategy is pushing towards digitization. This strategy is to respond to business developments that almost all lead to digitization. The concept of digitalization will be carried out on the delivery of goods. This item is launched through the Posgiro Mobile application, whose existence is currently still running and refined [11]. Another effort is to expand financial services and purchase of tickets and pay for electricity, water, and other daily necessities. Besides, it offers daily necessities such as electricity and telephone payments. PT. Pos Indonesia opens in longer hours. The office hours are from Monday to Saturday from 08:00 am to 09:00 pm, it eases the customers to transact both letters and packages.

Various strategies using a managerial view, but the strategic approach need adding another strategy from the perspective of architecture and urban design. In Indonesia, many post offices that existed since the colonial era are still running until now. The building categorized as cultural heritage buildings. It also has a strategic location near the zero points of the city or in the city center. With this location, there was a finding that the post office building had a high value [12-14]. In Bandung, the ground floor of the post office on Bangka Street has been commercialized as a rental space. Bandung Great Post Office Building is one of the colonial heritage buildings located adjacent to the town square and the pavilion, which was the government office at the time. Semarang post office building is located at the zero points of the city, close to the old square [13], and serves as a gateway to the old city. Medan post office lay at the zero points of the city, at the center of the Merdeka Square [14]. In several cities in Java, the location of the post office is on the Great Post Road (De Groote Postweg) and is close to the main square $[13,15]$.

The Solo post office, as a case study, is located along De Groote Postweg, which is built by Daendels (1809-1811) to connect cities on the north coast of Java. The establishment of the PT. Surakarta Post Office was inseparable from the development of the town of Surakarta into the modern urban design by the Dutch colonial government. The Solo post office is still in the status of a service and is still one with telegram and telephone, so it is called the PTT (Postal Telegraph and Telephone) service. During the Dutch Military Aggression II, many PTT offices were scorched, including the PT. Solo Pos Office. However, it is estimated that in 1945, PT. Solo Post Office turns into PT. Utama Post Office (rayon).

There have been many improvements from the managerial side of the post office to deal with the shrinking of postal service activities. However, not many discussed the potential of the location and commercial value of the building. Therefore, revitalization/ adaptive reuse efforts are important to develop the management of the post office in the future.

\section{METHODS}

This research conducts theoretical studies related to Post Office Buildings, and at the same time, excavating its historical aspects. Based on the academic discussion, it is hoped that a big theory or concept will be obtained. However, theories or concepts will not be brought to the field. It will only be used as background knowledge. New knowledge will be built from phenomena that arise from data in the field. Data collections about the Solo Post Office are in the form of architectural data such as floor plans, visible activities, and room functions. To build new knowledge on building conservation efforts, it is important to discover the uniqueness that comes from the character of the community and the character of Solo as a city that has a high historical value.

The data collection process will be obtained from used newspapers, history books, ancient maps, and conducting field surveys. Information analysis is carried out by analyzing the drawing of the map, which has been redrawn. Site location analysis will also be considered as a direction for conservation and revitalization efforts

\section{POSTAL SERVICE ACTIVITIES, FROM DE GROOTE POSTWEG TO THE RURAL AREA OF SURAKARTA}

\section{Development of Posts in the Age of VOC (Vereenigde Oost Indische Compagnie) (1602-1799)}

The arrival of the Dutch in Indonesia led to correspondence with the Dutch. In 1596, the arrival of Cornelis de Houtman had brought letters to the kings in Banten and Jakarta. Although correspondence has been established, the mailing must be directed to official officials, and its contents may not contain information about anything related to the company which trades in Indonesia. This regulation was carried out very hard and very strictly to keep the source of spices, which were very valuable at that time, unknown by the opponents of the company [16].

The first post office was established in Jakarta by Governor General GW Baron van Imhoff on 26 August 1746 to further ensure the security of resident's documents, especially for those who trade from offices outside Java and for those who come from and go to Holland. After the 
Jakarta Post Office was established, four years later, the Semarang Post Office was built to establish regular postal communication between the two places and to speed up its delivery. Postal travel routes at that time were through Karawang, Cirebon, and Pekalongan. Then, there was regular postal communication between Jakarta and Priangan, and between Semarang and the kingdom of Surakarta and Yogyakarta [8]. Arriving at Semarang, The Great Post Road is divided into two parts: one towards the east and the other heading south, namely to Surakarta and Yogyakarta. The city of Semarang is geographically connected with the inland cities, such as Ungaran, Salatiga, Boyolali, Kartasura, and Solo. The highway that goes through these cities to Semarang is an important highway to date [17]. The second type arises in the construction and expansion of networks for trading cities where factories are established, and fortifications for defense are designed. The establishment of the trading post first occurred along the northern coast of Java (Cirebon, Tegal, Semarang, Jepara, and Surabaya), and then widened towards strategic cities in the inland. It can be seen from the construction of the VOC fortresses, which widened from Ungaran (Fort Ontmoetinge), Salatiga (Fort Herstelling), Ampel (Fort Veldwachter), Kartasura, and Sala (Grootmoedingheid) [18]. The establishment of the service is related to adequate road infrastructure, as well as the remaining facilities of road construction in the form of pesanggrahan, wooden warehouses, and carts and horsedrawn carriages that can be utilized for the post office's infrastructure [17].

PT. Pos Indonesia has experienced various developments since the colonial era, through the period of independence, and until now. In some cases, PT. Pos Indonesia has a strategic role that has not or will never be replaced by any sophisticated technology. At least in two ways, in historical aspects and functions [8].

History of the Establishment of PT. Pos Indonesia (Persero)

PT. Pos Indonesia (Persero) is one of the companies engaged in the service business. This company provides services to the community in the form of communication services, financial services, and logistics services. Through the time, PT. Pos Indonesia transferred into a Business Entity, which was initially as a Service. In 1875 the post office was united with the telegraph service with the status of Service under the name Pos En Telegraapdievst. After that, it turned into a Company in 1906, as the Post Office in 1931, a State Company in 1960, the State Post and Telecommunications Company 1961, the State Post and Giro Company in 1965, the Post and Giro Public Company (Perum Pos and Giro) in 1976, Perum Pos and Giro in 1979, and PT. Pos Indonesia (Persero) from 1995 until now [19].

Based on the history of its establishment and its formation, several post office buildings, including those built in the colonial era, were in line with the construction of the Great Post Road (De Groote Postweg) connecting the cities on the north coast of Java. From the cities on the north coast of Java, the postal communication route leads toward the middle of the island of Java. The Dutch colonial built the first Post Office in Jakarta in 1746, and four years later, they created the Semarang Post Office. Then there is the allegation that the Solo post office was made a few years after the Semarang route to the kingdom of Surakarta and Yogyakarta. According to Hartatik [17], the Pantura Highway is not an entirely new road. Most of these highways used the Mataram Kingdom road. The coastal highway is also a medium for connecting diplomacy between Mataram and foreign envoys, such as VOC delegates.

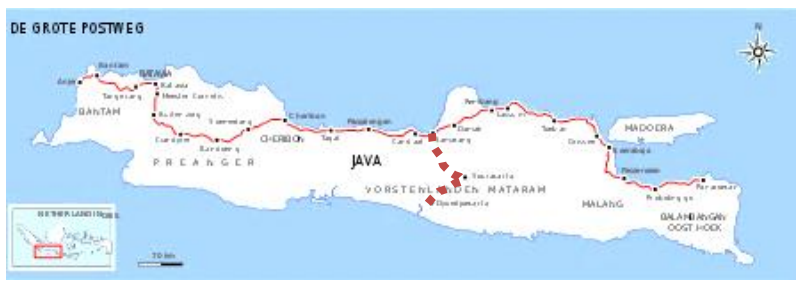

Figure 1 De Groote Postweg from Semarang to Surakarta and Yogyakarta

Thus, the postal service line and post office building were built along the Great Post Road (De Groote Postweg) on the north coast and heading inland like Parahyangan and Solo. The existence of the post became a link for diplomacy between Mataram and foreign envoys, such as the VOC. The post office building side by side with the fort in Solo along the railroad line in early 1862, from Semarang to Vorstenlanden. In addition to transporting sugar from Surakarta to Semarang, they use this road as well as the postal service. The post office buildings and their activities, as well as the modern urban planning of pioneering works in the city of Solo that still survive, are cultural heritage objects.

\section{SOLO, THE CREATIVE AND HERITAGE CITY TOURISM POTENTIAL}

Daendels made the Great Post Road (De Groote Postweg) from Anyer to Panarukan with the strategic military policy that requires fast transportation to enable rapid information systems as well. To fulfill this purpose, the GovernorGeneral Daendels, planned the construction of the postal highway by utilizing existing roads. Along this road, they regularly established post stations and stables at certain distances. The land transportation journey from West Java to East Java, which previously took 40 days, could be shortened to 6 days. After they finished the express highway, every $15-\mathrm{km}$ distance, there were lodging houses and horse exchange places that were the burdens of the people. Postal transportation is carried out with post trains of the same shape [20].

What about the Solo post office that is outside the Great Post Road (De Groote Postweg)? From Semarang city, the route continues east and south towards Surakarta. 
The post office lay on the north axis of the Surakarta palace in front of the citadel. The application of cosmological concepts in the palace complex refers to the north-south axis, where the castle is the central meeting point of the north-south. The city structure of the building has values that bind to the center. The strength of the identity and character of the city is unity with the existence of the Surakarta Sunanate Palace. The palace and surrounding areas are heritage cities that have heritage tourism potential, namely the Surakarta and Mangkunegara palaces, with local and foreign tourists' specifications.

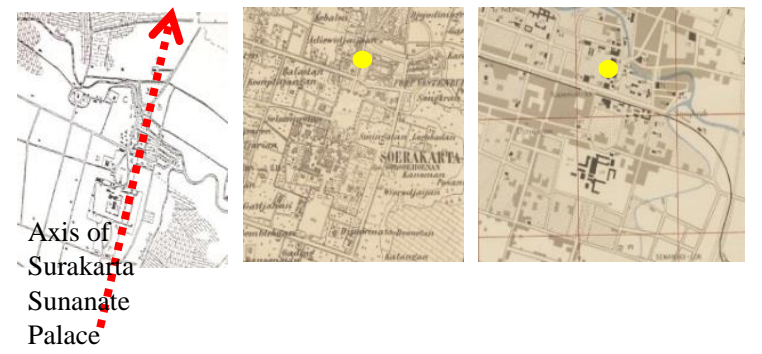

Figure 2 Post Office Location (yellow) at the axis of Kasunanan Surakarta Palace north axis (Source: Santoso 2008 \& kitlv.nl)

According to Hartono [21], the symbolic configuration of Solo and Yogyakarta is a sacred city. That city has a cosmic pattern, which includes a high axis, has a grid pattern, and a spatial hierarchy. However, based on Prayitno and Qomarun [22], the morphology of the Solo city has undergone a process of change. The Solo city has three different concepts of composition: the organic concept by the indigenous community, the colonial concept by the Dutch community, and the concept of cosmology by the Javanese court community.

In the first decade of 1900, public service services in Surakarta continued to grow, which was marked by the emergence of hotels, plumbing facilities, amusement parks, fortresses, museums, stadiums, schools, meat stands, telephones and photographers, libraries general, dentist, auction place, and public notary. Postal and telegram services are open every Monday to Saturday from 7:00 to 18:00. The Post Office also remains open on Sundays and holidays but only opens at 8:00 am to 5:00 pm. Surakarta, at that time, had become a busy city and became a center for trade, social and religious activities. Thus, the presence of the post office in the colonial era could not be separated from the colonial design of the cosmic concept city. The existence of the power of the colonial government was presented to the power of the palace/ local government.

Modernization in Surakarta since the existence of the Dutch began in the construction of railroad transportation in early 1862. It started from Semarang to Vorstenlanden through Karangjati, Kedungjati, then Surakarta, another part of Karangjati, Ambarawa, and then Yogyakarta. The railroad is used to transport sugar from Surakarta to Semarang. Trams are available to support transportation in urban areas. The construction of the tram in Surakarta for public transportation was carried out around 1900, starting from the city center, namely the Vteenburg Fort stop (in front of the post office). This tram is pulled by a horse that every post will stop to get on and off passengers [15].

In Surakarta, there are three different governments, namely Surakarta Sunanate, Kadipaten Mangkunegaran, and Dutch Resident. The Dutch administrative area, located around the Resident offices, fortresses, and Military Camps. Modernization in the colonial era was intended to maintain the design of the city with a modern system (European type) that was equipped with communication networks (such as telephone, and newspaper); transportations (such as trains, roads, and trams); supra economic structure (such as banks and pawnshops); supporting facilities for the city (such as churches, school, sports field, societies, and theater building). Public service facilities (such as pharmacies, hospitals, post offices, and telegraphs), as well as city recreation facilities, such as Balai Kambang Park, Tirtonadi, Partini Tuin Botanical Garden, Partinah Bosch, and Partimah Par, supported the city [18].

In the Solo city morphology, there are two tourism potentials, namely the Heritage tourism potential and creative tourism. The Indonesian Heritage City Conservation Charter in 2013 states that "heritage cities are cities or regencies that have superior heritage assets in the form of knits of natural heritage and sustainable cultural heritage which include physical elements (artifacts, buildings, and areas with open spaces) and elements of life, economic, socio-cultural". The main reason why heritage cities need to be preserved is that these heritage cities have important values, including the value of national identity/ identity, historical, environmental, social, political, ideological, economic and cultural aspects which if managed optimally in the context of sustainable development will provide benefits for improving environmental quality and community welfare [23].

Solo is a potential city to be developed into a creative tourism city. Creative tourism is a tourism concept that changes the mindset of tourists from buying products to the buying experience. A creative city is a place where people feel that they can think, act, plan with imagination, and also contain people who have a combination of knowledge so deep about the city, where many people with different qualities are allowed to develop themselves. The author observes that the above aspects are appropriate to describe the current condition of the city of Solo. If only relying on historical buildings, the development of the city will stagnate. Therefore it is very important to develop a city based on creativity so that the City of Solo can develop into a city of creative tourism [24].

From the history of Solo from a traditional city to a modern one in the Dutch colonial era, the position of the post office played an essential role in the formation of the postal line that passed through Semarang to Surakarta. Some historical relics in Solo since the city stood as a kingdom until it became a modern city has an important meaning in supporting the city's tourism. 


\section{ADAPTIVE REUSE OF SOME PARTS OF SOLO POST OFFICE BUILDING}

PT. Pos Indonesia (Persero) of Surakarta is located in Jalan Jenderal Sudirman, No. 8, adjacent to the Vastenburg Fortress and Surakarta City Hall, which is a Technical Implementation Unit (UPT) as well as a Central Management Post (SPP) with a fairly complete function in terms of service activities[19]. According to Yuhida [8], the proposed activities at the Solo Central Post Office are Express Pos, Post Package, and Ordinary Post (Standard). Some of these products are sold on the internet through the activity of online businesses into people's choices in trading transactions. With the online system, there is a level of use of postal services by the public who are less interested in using Post Office services. Various commodity prices have increased; this has resulted in decreased shipping activities. Reviewing the cost of fuel costs increased dramatically so that the public demand for shipping and delivery services, both goods and postal, decreased.

The decrease has an impact on shrinking the spaces. Based on the field survey, the 3rd floor of this building can be used for other activities. Collaboration with other parties for commercial activities can be done with the best practical post office of Jalan Bangka Bandung, which rents the 1st floor for commercial activities. The view from the 3rd floor to the historical city of Mataram and the colonial era is very potential to be developed into a café or restaurant.

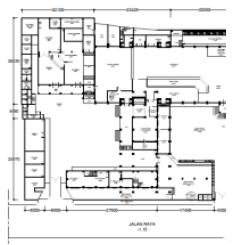

$1^{\text {st }}$ FLOOR

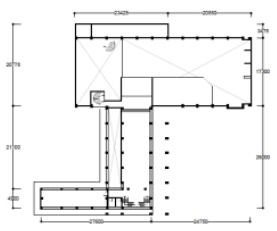

$2^{\text {nd }}$ FLOOR

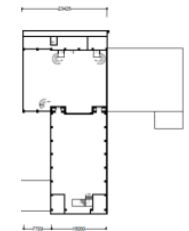

$3^{\text {rd }}$ FLOOR 3

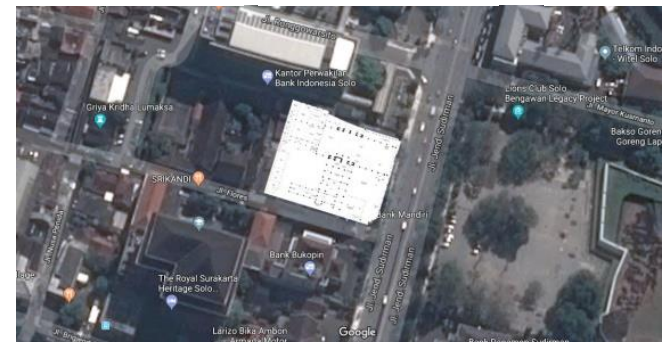

Figure 3 The post office location in front of Vastenburg Fort; the $1^{\text {st }}, 2^{\text {nd }}$, and $3^{\text {rd }}$-floor maps

The development of commercial businesses is, of course, not separated from the vision and mission of PT. Pos Indonesia (Persero) as a company in the field of business services that are providing reliable means of communication for the public and the government to support National Development and strengthen the unity and integrity of the nation and State. Another mission is to develop businesses that rely on improving service quality through the application of appropriate science and technology to achieve customer satisfaction and provide optimal added value for employees, shareholders, the community, and business partners [1].

In developing commercial business services with the private sector to develop the 3rd floor of the Solo post office or the 1st floor part, a global approach is needed, so that what is presented has a 'Message of Value' that can be conveyed according to the authenticity of the building's architecture. The message value comes from the historical aspects of postal services as a media liaison for diplomacy between Mataram and VOC. The above principles are things that must be fulfilled first in the conservation work of Solo post office building. It is to ensure the building and postal services that have the Sense of Continuity and Identity. Besides, it also served as Symbolic and Culture Values of Art, Aesthetic History, and Archaeology. A symbol of postal service delivery since the colonial era and Mataram. The historical value contained in the postal service is the historical value of the postal track, the postal building as cultural preservation, and postal service activities that are still essential from the colonial era to the present.

\section{CONCLUSION}

Some innovations in postal services to address the post office collapse issue have been carried out by PT. Indonesian post. Business transformation covers all aspects of business, human resources, strengthening of subsidiaries, developing new products, and pushing towards digitalization. Financial services and ticket purchases and payment for electricity, water $[8,19]$. Not only in the Solo Post office, but this innovation and transformation have been carried out in various countries. $[1,3,5,7]$. Some strategies carried out the focus on managerial improvements.

The research findings are 1) the post office was designed by the Dutch colonial to better guarantee the security of residency letters, especially for those who trade from offices outside Java and for those who come from and go to the Netherlands; 2) the existing lane as a postal lane that was built in 1809-1811 is the link of cities in northern Java [13] and inland [18], so there is potential for managerial improvement from the architectural and urban design point of view. Adaptive reuse efforts were found for post office buildings to utilize empty spaces due to reduced postal service activities. Some counters are divided according to the type of service, such as mailbox counters and also several workspaces. Sharing space between postal activities and additional commercial activities to support postal services is very possible. Of the three floors of the Solo post office, there is the potential for the third floor to be considered as a commercial area. Efforts to use and adaptive reuse part of the post office building will support the mission of the post office to develop businesses that rely on improving service quality [1]. The solo area has potential as cultural tourism and creative tourism. This breakthrough finding can answer the question of the 
collapse of the post office in Indonesia due to the presence of social media and delivery of goods through private shipping services.

Adaptive reuse of post offices with a sharing space model between commercial activities and postal service activities is expected to support Solo City tourism promotion efforts to be developed into creative tourism cities. Creative tourism is a tourism concept that changes the mindset of tourists from buying products to buying experience [24]. Creative tourism that combines the knowledge about the history of the postal track, post office building, and postal service activities that still exist until now will be a unique attraction that has not been discussed in the world of tourism.

\section{RECOMMENDATION}

Some recommendations that must be applied in the development of the Solo post office are:

- It is necessary to identify the postal activities that still exist and become a selling point that can be seen directly by tourists

- It is necessary to apply the applicable conservation principles: maintaining the authenticity of the form, materials, technical craftsmanship, and layout.

- There needs to be coordination with the Central Java Archaeological Heritage Preservation Center.

\section{ACKNOWLEDGMENT}

Thanks to the Department of Architecture, Faculty of Engineering, the University of Diponegoro, which has provided community service funds in 2019. Much appreciation also addressed the post office in Semarang, which has provided recommendations for the implementation of activities in the Solo post office, Central Java, Indonesia.

\section{REFERENCES}

[1] P. I. Mayangsari, M. S. Soeaidy, and W. Y. Prasetyo, Inovasi PT. pos indonesia, J. Adm. Publik, vol. 1 , no. 2 , pp. $248-256$.

[2] S. Wahyuningsih, Pengembangan Layanan Jasa Pengiriman PT. Pos Indonesia Untuk Kebutuhan Masyarakat Di Kota Bandung Shipment Service Development Of PT. Pos Indonesia For Society Needs in Bandung, J. Penelit. Pos dan Inform. vol. 3, no. 1 (2013).

[3] A. Khator, The Relevance Of Traditional Post Office Services In The Growth, Int. J. Bus. Manag. Rev., vol. 1, no. 2 (2013) 31-42.
[4] E. Ankrah, The Impact Of Technology On Postal Services In Ghana, vol. 4, no. 01 (2015) 125-129.

[5] D. Byrne, A New Vision for Post Office Services in Ireland. A Transformational Programme for Ireland's Post Office Network.

[6] K. R. Kosar, The U . S . Postal Service : Common Questions About Post Office Closures, 2012.

[7] G. Beyond and A. Report, Service Quality and Innovation in Malaysian Post Offices : An Empirical Study, no. 2006, pp. 55-66, 2015.

[8] S. Yuhida, Peranan PT. Pos Indonesia (Studi tentang Kantor Pos Solo dan Peranannya dalam Bidang Jasa bagi Masyarakat), Universitas Sebelas Maret Surakarta, 2011.

[9] E. Djumena, Isu PT. Pos Indonesia Bangkrut, Ini Kata Kementerian BUMN, Kompas.com, Jakarta, 23Jul-2019.

[10] PT. Pos Indonesia Tepis Isu Bangkrut, CNN Indonesia, Jakarta, 2019.

[11] PT. Pos Indonesia Diterpa Isu Gulung Tikar, Ini 6 Kenyataannya, okefinance, Jakarta, 2019.

[12] S. Rukayah and S. Juwono, Arsitektur Dan Desain Kota Hibrida Pada Kantor Pos Dan Alun-Alun Di Medan, Tataloka, vol. 20, no. 3 (2018) p. 317.

[13] R. S. Rukayah, S. Juwono, E. Sri, S. S. Dhanang, and R. Puguh, Post Office and Traditional City Square As City Linkage in Java, pp. 0-6, 2019.

[14] S. Yuwono and R. S. Rukayah, Bangunan Heritage Kantor Pos Medan. penerbit Undip, 2018.

[15] R. Y. Priyantoko, Alun-alun di Pusat Kota Gementee di Pesisir Utara Jawa Pada Awal Abad XX Masehi, Universitas Indonesia, 2010.

[16] Y. A. Pradipta, Perancangan Visual Book Sejarah Pos Di Indonesia Masa Pra-Republik Hingga Kemerdekaan Republik Indonesia Perancangan Visual Book Sejarah Pos Di Indonesia Masa Pra-Republik Hingga., Program Studi S-1 Desain Komunikasi Visual Jurusan Desain Fakultas Seni Rupa Institut Seni Indonesia., 2015.

[17] E. S. Hartatik, Dua abad jalan raya pantura Sejak Era Kerajaan Mataram Islam hingga Orde Baru. Yogyakarta: Nurmahera, 2018. 
[18] Riyadi, Modernisasi Kota Surakarta Awal Abad XX, J. Candi, vol. 06, no. 2 (2013).

[19] A. M. Annawawi, Strategi Promosi Dalam Meningkatkan Volume Penjualan Terhadap Produk Sopp Pos Pada Pt . PT. Pos Indonesia ( Persero )

Surakarta, . Universitas Sebelas Maret Surakarta., 2010.

[20] P. A. Toer, Jalan Raya Pos, Jalan Daendels.

Lentera Dipantara, 2005.

[21] S. Hartono, Jogjakarta and Cakranegara, pp. 1-11, 1972.

[22] B. Prayitno and Q. Qomarun, Morfologi Kota Solo (Tahun 1500-2000), Dimensi (Jurnal Tek. Arsitektur), vol. 35 , no. 1 (2007) 80-87.

[23] Mengembalikan Identitas Kota Pusaka.

Kementerian Pekerjaan Umum dan Perumahan Rakyat, 2015.

[24] A. B. Setyawan, Pengembangan Kota Solo Sebagai Kota Wisata Kreatif., Universitas Sebelas Maret Surakarta., 2013. 